\title{
Necessary precautions
}

\section{Richard Davenport-Hines}

A History of Contraception: From Antiquity to the Present Day. By Angus McLaren. Basil Blackwell: 1990. Pp. 275. £25, \$36.95.

CONTRACEPTION has been as perennial a human need as sex itself. The ways in which it has been practised, together with the social, religious and legal inhibitions which have been placed on it, are central to human experience through the ages, yet have hitherto been largely erased from the historical record. Just as almost none of the modern films and television programmes that feature acts of sexual intercourse ever refer to the contraceptive precautions which the characters presumably take, so historical attempts at fertility control are mostly unmentioned. Professor McLaren's scholarly, comprehensive but sprightly and readable History of Contraception is therefore a major piece of historical reclamation and discovery which will interest sociologists, historians and social anthropologists as well as less specialist readers.

He draws on a wide range of demographic, medical, literary, religious and philosophical sources across 2,000 years, and writes lucidly with an appropriate touch of humour. He is mercifully free from the domination of French doctrinaires like M. Foucault. Previous books treating the history of contraception have tended to offer an ethnocentric and even male supremacist view of the subject. in which women are depicted as the passive beneficiaries of the sudden triumph of twentieth-century scientific reason over fertility. ignorance and religious superstition. In fact. as McLaren shows with a mastery of his material that never palls, there have been attempts at fertility control since the era of the Greek city states. The emphasis that he gives to women's experience of contraception, and to women's own efforts at fertility control before the twentieth century, is particularly sensitive, shrewd and salutary. Sexuality has always been "an independent variable" in history, he writes; the continuous, richly complex ways in which reproductive decision-making has been perpetually entangled in a web of economic, social, cultural and gender relations makes a fascinating tale which goes to the heart of human bchaviour.

McLaren presents much interesting material on such subjects as condoms or herbal and chemical contraceptives (of varying efficacies), but one of the clearest themes to emerge from his book is the persistent recourse to abortion as the only reliable way of regulating fertility. "The proper thing to do is to limit the size of each family, and if children are then con- ceived in excess of the limit so fixed, to have miscarriage induced before sense and life have begun in the embryo" - so recommended Aristotle. Throughout subsequent ages the practice seems to have

IMAGE
UNAVAILABLE
FOR COPYRIGHT
REASONS

Fearsome 1930s contraceptive devices.

been unexpectedly widespread and legitimated. In Europe (from which most of the evidence of the book is drawn) there was a traditional notion that, until animation

\section{Informational school}

\section{Gunther S. Stent}

The Emergence of Bacterial Genetics. By Thomas D. Brock. Cold Spring Harbor Laboratory Press: 1990. Pp. 346. \$55.

MOLECULAR biology became a distinct discipline in 1953, upon the marriage (brokered by Watson and Crick's discovery of the DNA double helix) between two formerly single bodies with separate research agendas. One of the newlyweds was the structural school, concerned with the three-dimensional form of living molecules. Its experimental material consisted mainly of crystallized biological substances, which were submitted to $\mathrm{X}$-ray diffraction analyses. The other was the informational school, concerned with the transmission and expression of hereditary information. Its experimental material consisted mainly of bacteria and bac- took place, married women were entitled to seek to restore their menses, although there was always more hostility to abortions necessitated by the results of fornication. But generally, until the nineteenth century, "many insisted on viewing abortion as simply one more step on a continuum of fertility-controlling practices".

It might seem that there is not much in the way of description or analysis to be written about the miserably unsatisfactory and anxious act of coitus interruptus. But McLaren is no less illuminating when he assesses the prevalence of this contraceptive technique in Czechoslovakia in the 1970s than when he quotes a poetic description of withdrawal written in the seventh century $B C$ by a mercenary from Paros. Throughout he relates this attempt at fertility control to the different types of society in which it was practised. Although McLaren's interpretative synthesis is in most respects complete, in writing about coitus interruptus he overlooks the influential body of medical and quack opinion which (in Britain from the seventeenth to the early twentieth centuries) urged men to make penetration as quick as possible to avoid venereal disease, and which particularly warned that a woman was more likely to transmit such an infection the nearer she approached to orgasm herself. Withdrawal was widely practised as a prophylactic against venereal infection as well as a contraceptive technique. As Lord Rochester described in his poem 'The Debauchee',

I send for my whore, when for fear of a clap,
I dally about her, and spew in her lap.

Richard Davenport-Hines is at 51, Elsham Road, London W14 8HD, UK.

terial viruses, which were submitted to genetic analyses.

Thomas Brock's The Emergence of Bacterial Genetics provides an extensively documented history of the rise of the informational school. Brock has taken the standard chapters of textbooks on the genetics of bacteria and their viruses classical genetics and bacteriology, mutation, conjugation, bacteriophage, lysogeny, transduction, transformation and gene expression - and expanded them by adding direct quotations from original research publications and presentations of experimental details. He also quotes and summarizes material he found in archival holdings of letters and private papers of some leading members of the informational school and reports on consultations and correspondence with many people who have personal knowledge of the developments covered.

Thus this book offers newcomers to bacterial genetics a wealth of experimental data, as well as peeks behind the scenes. This is especially true of the work of Joshua Lederberg, the discoverer of 